\title{
Sam se učim
}

O samostojnem učenju je bilo že marsikaj zapisanega. O njem se vse več govori. Ljudje se vedno bolj zanašajo na lastno pot do znanja, saj pravijo: znanja mi zmanjka, gledam ponudbe takil in drugačnih izobraževalnih programov, vendar prav tega, kar jaz potrebujem, ne odkrijem nikjer. Podam se na lastno pot iskanja znanja.

To se zgodi marsikomu, ker so potrebe po znanju zelo osebna zadeva. Tečaj ali seminar - če na to temo sploh obstaja - sicer lahko pokrije del potrebnega znanja, vse ostalo znanje pa moramo zapolniti po osebni poti.

Stvari najbolje obvladano, če združujemo različne načine izobraževanja: množične oblike izobraževanja prek medijev, skupinsko izobraževanje na seminarjih in konferencah, največji delež učenja pa ima samostojno pridobivanje znanja po zelo raznolikih osebnih poteh. In zadnjega je danes vedno več. Nimamo časa čakati, da bo kje razpisan seminar na našo temo. Morda je to, česar bi se radi naučili, tako posebno, da takega tečaja ali seminarja splol nikoli ne bo, ker ni povpraševanja.

Ko ljudem zmanjka znanja, še vedno najprej pomislijo na skupinske oblike učenja: so uradnejše in imajo več ugleda, zdijo se sbolj pravo učenje». Raziskave, ki jih že več let ponavljamo na vzorcilt visokoizobraženih ljudi srednje starosti, dokazujejo, da samostojnega neformalnega izobraževanja ljudje ne jemljejo tako resno, kot recimo pouk ali druge oblike skupinskega izobraževanja z učiteljem. Zato nočejo govoriti o stvareh, ki so se jih sami naučili. Celo prikrivajo jih, kot bi jih bilo sram, da so se nekaj naučili kar tako, sami. Tak odnos do samostojno pridobljenega znanja, včasih tudi po nenavadnih osebnih poteh, povzroča, da samostojno pridobljeno znanje ni primerno družbeno priznano in tudi ne potrjeno s spričevalom.

Samostojno učenje je spontano, prijetno in veliko bolj pisano na kožo posameznega človeka. Vsak svoje učenje prilagaja konkretnim pogojem, osebnim možnostim in posebnim prilikam. Samostojno učenje je vgrajeno v življenje posameznika.

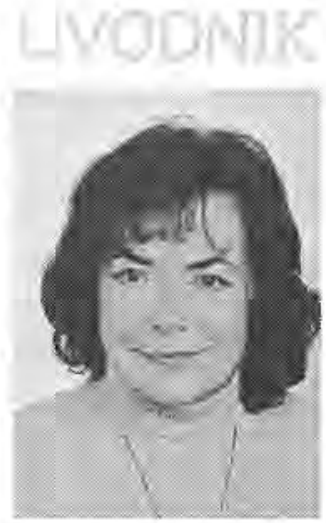

Prof. dr: Ana Krajnc

Ta se ne gre nekam izobraževat (npr: na seminar), ampak je njegovo izobraževanje način življenja. Zato je samostojno učenje pogosto uspešnejše od skupinskega. Človek je bolj spri stvariø, se učenju ves preda, uči se z interesom ali pa se sploh ne uči. Ne da bi se prav zavedal, se nauči nekaj novega.

Ko smo ljudi spraševali, kaj so se sami naučili v zadijih dveh letih, katere osebne učne projekte nam lahko naštejejo, so bili pogosto v zadregi. Nekateri so imeli občutek, da se sploh niso izobraževali in da nimajo kaj našteti. Dejansko pa so se naučili celo več stvari, ne da bi o tem posebej razmišljali.

Kateri so glavni viri znanja pri samostojnem učenju? Veliko pridobimo iz knjig in ostalih pisnih virov. Skoraj use se dobi tudi na internetu, če le ne izgubimo preveč časa za iskanje. Vsakodneven vir novih spoznanj so javna občila. Vedno več ljudi živi v urbanih okoljih in v stikih z drugimi ljudmi izvemo mnogo novega. Še pogostejši kot osebna srečanja pa so telefonski pogovori. Z mobilnim telefonom lahko človek ves čas komunicira in od povsod.

Človek se postopno pomika proti tistemu, kar bi rad vedel. Pri tem povezuje med seboj razne poti: pogovor; opazovanje, branje, učenje pri delu, poskuse in zmote, telefoniranje, razmisljanje. Razne vire po potrebi združuje, jih kritično presoja, primerja in sam odloča o tem, kaj bo sprejel (se naučil) in kaj se mu zdi nepotrebno ali neverjetno.

Kdo se lahko samostojno uči? Se lahko vsak človek samostojno učti?

Samostojno učenje je trden, notranje povezan, načrten in $k$ cilju (znanju, ki ga nekdo potrebuje) naravnan proces. Potrebe po samostojnem učenju so vedno splošnejše. Ni vseživljenjskega izobraževanja, če ne prevlada samostojno učenje nad skupinskim izobraževanjem. Zato je eden od osnovnih ciljev izobraževanja naučiti človeka učiti se. K remu vzgojnemu cilju dodajajo se: naučti človeka komunicirati, odloçati in izbirati ter pripadati. (Kidd, Jarvis, Dohmen)

$Z$ razvojem je postalo preživetveno pomembno, da 
se zna človek ves čas sam učiti in stalno sprejema nova znamja. Ni toliko pomembno, koliko človek zna $v$ danem trenutku, ko ga sprejemamo $v$ službo, ampak koliko je učljiv. Z visoko osebno učljivostjo bo kmalu postal kompetenten za zaupane mu naloge. Učljivost je podlaga za zaposljivost osebe: če ne bo delal tega, bo pa kaj drugega.

Kljub vsesplošni potrebi po samostojnem učenju se nekateri ljudje ne morejo sami učiti. Za samostojno učenje so potrebne določene osebne lasmosti in razvite sposobnosti. Kako uspešno bomo pridobivali novo znanje, je odvisno tudi od tega, koliko znanja že imamo. Več vemo, bolje se bomo znašli pri novih vsebinah. Samostojno učenje je neke vrste spirala: več kot znašs, več se lahko naučišs.

Ključnega pomena za samostojno učenje je motivacija. Ko se nekdo loti izobraževanja po samostojni poti, nima učitelja, ki bi ga priganjal $k$ učenju in kontroliral, nima mentorja, ki bi bedel nad njim. Odločati se mora sam. Odločanje spremlja ves proces samostojnega učenja: o poteh učenja, o tem. kako zgoščeno se bo učil in kakšen bo njegov ritem učenja, ali je to, kar zna, dovolj, ter kje in kdaj bo svoje znanje preizhusil. S tem je za svoje učenje tudi sam odgovoren.

Kako zagnan bo pri učenju in iskanju primernih učnih virov, je odvisno od motivacije. Naenkrat je človek pri izobraževanju odvisen od rebe. Bolj motivirani najdejo pot do najnenavadnejsih virov za učnje in presenetijo $s$ tem, kako vztrajno in zagnano se učijo. Po drugi strani pa se bo za učenje nemotiviran človek bolj nagibal k temu, da se prepusti drugim in sledi poučevanju ali pa se učenja sploh ne bo lotil. Samostojno učenje je zelo osebno obarvan proces.

Smiselno branje, razumljivo pisno izražanje, sposobnost poslušanja in vživljanja v druge ter jasno ustno izražanje so izhodiščni pogoji za samostojno učenje. Za samostojno učenje človek potrebuje tudi razvite organizacijske sposobnosti, sposobnost načrtovanja in predvidevanja, sposobnost analitičnega in sintetičnega mišljenja ter druge miselne funkcije, raziskovalne spretnosti, sposobnost ločevanja bistvenega od nebistvenega.

Marsikdo nima vsega naštetega. Samostojno učenje zlasti ni mogoče pri funkcionalno nepismenih ljudeh. Ločnica med ljudmi, ki so sposobni za samostojno učenje, in tistimi, ki niso, je dokončana gimnazija ali kakšna druga primerno zahtevna štiriletna srednja šola. To pa je tudi ločnica med funkcionalno pismenimi in nepismenimi ljudmi. Pri funkcionalno nepismenih opazimo, da se tudi sami izogibajo izobraževanju, čeprav jim manjka največ znanja in je osebni razvoj še na zelo nizki ravni. Brez razvitih sposobnosti in znanja so ti ljudje preživetveno ogroženi. Danes človek ne živi od svojih mišsic, ampak od pameti (dobrih idej, osebne pobude, visoke stopnje samostojnosti itd.).

Študent uravnava samostojno učenje tudi po povratnih informacijah iz okolja. Dajejo mu orientacijo, koliko se je že naučil, kaj ga še čaka, kako daleč jez učenjem. Bolj jasni mu postanejo tudi končni cilji: kaj bo treba znati. Po odzivih drugih ljudi si oblikuje kriterije za sprotno ocenjevanje, kako uspešen je pri svojem študiju. Samosiojno učenje je testio povezano s socialnimi stiki študenta, saj lahko spodbudno vplivajo na njegovo motivacijo.

Samostojno učenje je zahtevno. Študent nosi vso odgovornost in odloča sam. Bo znal poiskati pravo znanje? Bo pot do uspeha res optimalna? Ko nastopi napomejsa faza učenja, jo mora sam premagati, sam si postavlja kriterije za uspešnost učenja. Odloča o tem, kdaj bo s svojim znanjem zadovoljen ali ne. Navadno udi sam napravi korak od naučenega $k$ uporabi znanja v praksi.

Po drugi strani je samostojno učenje najbolj prilagojeno sedanji stopnji razvoja. Prijetno je in študentu daje veliko svobode, možnosti izbiranja, prilagajanja učenja svoji Življenjski situaciji in konkretnim razmeram. Student se lahko ravna po svojem razpoloženju. Uči se v domačem ali zanj najbolj prijetnem okolju, uči se v naravnem okolju: poišce nekoga, ki to že dela, opazuje pojav neposredno $v$ naravi, pogovarja se neposredno $z$ avtorjem itd. Samostojno učenje je učenje z radostjo, učenje zaradi neke potrebe, nuje in hkrati po lastni izbiri.

S samostojnim učenjem ljudi zaide izobraževanje v vse pore življenja, postane vsě̌ivljenjski proces in tako nastaja sučeča se družbaß. Teden vseživljenj. skega učenja ima v Sloveniji večletno tradicijo. Predstavi nam pestrost možnih oblik izobraževanja. Tudi Slovenija teži k temu, da bi postala učeča se družba. 